1st International Conference - Global Ethics - Key of Sustainability (GEKoS) | May 15th, 2020 | Bucharest, Romania

\title{
Bank Delinquency in Romania
}

\author{
Andreea ANTON \\ https://doi.org/10.18662/lumproc/gekos2020/15
}

How to cite: Anton, A. (2020). Bank Delinquency in Romania. In A. Grigorescu \& V. Radu (vol. ed.), Lumen Proceedings: Vol. 11. 1st International Conference Global Ethics - Key of Sustainability (GEKoS) (pp. 141-149). Iasi, Romania: LUMEN Publishing House.

https://doi.org/10.18662/lumproc/gekos2020/15 


\title{
Bank Delinquency in Romania
}

\author{
Andreea ANTON1
}

\begin{abstract}
Romania has gone through a period of economic expansion in terms of the banking system. Although over the last 15 years, banks have been hit by a strong economic crisis, with numerous laws aimed at helping the population on the grounds that there is a partnership between it and banks, the Romanian banking system looks like an efficient banking system, having all performing banking system indicators with a high level of capitalization. The high levels of nonperforming loans are subject to global approaches because, although the banks and the states concerned are mainly responsible for addressing this problem, bank delinquency has a fairly clear European dimension. There is a possibility of spreading the effects of non-performing loans from Member States facing this problem, so it has been decided to extend an action plan.
\end{abstract}

Keywords: delinquency; crisis; provisions; non-performing loans; risk.

\footnotetext{
${ }^{1}$ Faculty of Economic Sciences and Public Administration, "Stefan cel Mare" University of Suceava, Romania, e-mail: anton.andreea20@yahoo.com

(c) The Authors, LUMEN Conference Center \& LUMEN Proceedings.

Selection and peer-review under responsibility of the Organizing Committee of the conference
} 


\section{Introduction}

The banking system has a very important role, being an essential link in the saving-investment process, being a priority its stability on the agenda of public authorities. The central bank has the primary role of ensuring efficient monitoring that will contribute to achieving the stability and viability of the entire financial system, thus preventing systemic risk. Therefore, central banks have developed methods and processes that have the role of continuously monitoring and evaluating banks, in order to prevent financial crises or other unpleasant surprises regarding the entities of the banking system[1].

As for Romania, it has gone through a period of economic expansion, if we refer to the banking system. After the crisis that appeared in 2008, numerous laws appeared meant to help the population, which wanted to be the pillar of an efficient banking system, with performance indicators and a high level of capitalization. Among the laws meant to help, but later declared inefficient or unconstitutional, we mention the law of giving in payment, the law of taxation of bank assets, the law of capping interest on mortgages and consumer loans, normative acts aimed at eliminating the enforceability of loan agreements and capping amounts which can be requested by debt collectors.

Non-performing loans are those loans in which the borrower cannot pay interest and principal on time. If the payment term has been exceeded by more than 90 days and the loan is considered unlikely to be repaid, it is classified as non-performing. In general, delinquency in the banking system has increased as a result of the financial crisis, subsequent recessions, legislative changes and the internal context.

Banks' performance is affected by the large volume of nonperforming loans because they are not income-generating, thus reducing its profitability, they can even cause losses that diminish the bank's capital. At the same time, non-performing loans block significant amounts of financial and human resources. The mechanism of a bank is relatively simple: from the money of depositors coming from deposits and savings accounts, it is used for lending to the population and companies. If the situation of granted loans worsens, the bank becomes incapable of repaying the money obtained from savings. Provisions are intended to cover the losses of credit institutions. In the worst cases, the viability of a bank can be questioned, which could destabilize the financial system.

Risk management at the banking level has always been a problem, but in the past it has not had the overwhelming importance it has now. This 
has a simple explanation, the actual risks were less numerous, reduced in impact, and the financial system and markets were relatively stable [2].

\section{Problem Statement}

At European level, the Banking Union is organized, a banking supervision and resolution system that operates according to rules and regulations issued by the European Union. The countries that have joined the euro area are part of this Union, noting that other countries can also opt to participate. The objectives of the banking union are mainly to ensure a safe and reliable European banking system, resistant to future financial crises, to strengthen the financial system of the European Union, to prevent situations in which taxpayers' funds are used to save troubled banks.

Non-performing loans are the subject of global approaches, with banks and the state being directly involved, with bank delinquency having a fairly clear European dimension. The propagating effect of non - performing loans from Member States facing this problem has led to the construction of an action plan.

A reference book that was a real starting point for the constructionof this article was"'The end of Alchemy", Mervy King (2016). He points out that the last two decades have brought unprecedented growth and economic stability, followed by the worst banking crisis in industrialized society. We can say that history repeats itself in the sense that the current pandemic has turned trust into distrust. As Cristina Peicuti (2011) and Goodhart (2008) notes "liquidity and solvency are two inseparable faces of banking, so impossible to break from each other" we can conclude that these two indicators are the ones that prove the destabilization of the banking situation.

Also, the main dates were extracted from the National Bank of Romania and European Bank reports.

\section{Research Questions/Aims of the research}

Vulnerability of companies, unpaid loans of individuals and legal entities, rising real estate prices, declining investor confidence in the market, lack of financial education among the population and the new pandemic are just some of the causes of banking delinquency. If we take all this into account, we can quickly say that we are heading for the worst financial crisis in several centuries. We can add to the causes listed above the technical unemployment, the loss of many jobs permanently, the closure of important businesses, here mentioning the trade in closed spaces of non-food items, restaurants, hotels, terraces, etc. 
We can talk about outlining clear objectives in the articles, such as determining the specific causes of banking delinquency, the solutions that come to improve it, but also the characters involved in this endeavor.

\section{Research Methods}

For the elaboration of this study, reference works on the topic of banking delinquency were consulted, which led to the understanding of the different approaches and methods regarding the evaluation of the crisis generated by the non-payment of rates. First, the methods underlying the assessment of the degree of banking delinquency were studied from the literature, and secondly, the views of bankers within the NRB were analyzed, which determined the reasons behind the problems of non-payment of rates by appropriate techniques, tools or models.

The research methodology used in the elaboration of this article was based on information, documentation, analysis and synthesis of data from previous research in the literature.

The research methodology consists in the quantitative analysis of the banking delinquency phenomenon, using means such as the dialect method, which includes components such as synthesis, analysis, induction and deduction, observation, comparison.

\section{Findings}

The last three decades have been the best, but also the worst in recent centuries. They were marked by a period of financial growth and stability, followed by one of the most severe banking crises that shook all sectors of the economy in 2007-2008. After this crisis, in which the most stable banks suffered, this propaganda spread globally, the states began to recover, the last decade being marked by economic development[3].

The year 2020 was marked by the pandemic of the influenza virus, which paralyzed the whole humanity and implicitly the world economy. Experts say there is a bigger financial crisis than there was about 10 years ago. The pandemic is not the only cause that will trigger the crisis, we can mention here the pursuit of the financial market actors after the biggest possible gains, in the conditions in which they do not take into account the assumed risks.[4].

Non-performing loans have increased in the last three years, so that the Central Bank states that the risk of non-payment of loans is very high. It is determined by numerous factors related to the economic discipline of the population, the standards, the norms and the legislative regulations to which the banks in each country are subject. The stagnation of the increase in 
banking delinquency in the last period before the pandemic is due to the large number of loans granted on the market, not to the improvement of the population's behaviour.

The last years have been marked by a paradox, perhaps less known, that of the growth directly proportional to the financial assets with the market demand. Paradoxically, the higher the price of shares or bonds, the more interested buyers are in investing. The same happens with the demand for loans, the more accessible they are, the higher the price of assets, more and more buyers are determined to borrow, thus pledging through purchased assets that are increasingly expensive[5].

At the same time, the aspect of prices in the bank-client relationship must be in agreement with the banking marketing, so that transparency is one of the main qualities of this relationship. Banks must clearly display the fees, interest, rates charged.[6].

Table 1. Risk map for financial stability in Romania

\begin{tabular}{l} 
Deteriorating investor confidence in emerging economies \\
governmental sector \\
gove of non-repayment of loans contracted by the non- \\
$\square$ Tightening macroeconomic balances \\
$\square$ Lalance sheet of companies \\
\hline Rising real estate prices
\end{tabular}

Severe systemic risk

$\square$ High systemic risk

Moderate systemic risk

Low systemic risk

Note: the color indicates the intensity of the risk, the arrows indicate the perspective of risk in the next period

Source: www.bnr.ro

Banks periodically review their processes, strengthen their capacity to manage risks and consolidate operations, respecting international standards of good practice, the ultimate goal being to achieve maximum efficiency [7]. 
The year 2017 brought with it an increase in the total debt of the population, due to the significant increase in mortgage and consumer credit granted by banks and NFIs. Changing the interest rate trend of the national currency may put pressure on the ability of vulnerable borrowers to pay their debts, which would lead to an increase in indebtedness to an unsustainable level[8]. Therefore, measures have been taken in this regard by introducing a new way of calculating the reference index for consumer credit. The quarterly reference index (reference index for consumer loans, abbreviated RICL) is calculated as the arithmetic average of the daily interest rates of interbank money market transactions, determined for the previous quarter, and the daily average is calculated as a weighted average of interest rates on deposits with the volume of transactions on the interbank money market during a working day[?].

At the same time, the risk of non-payment of loans is determined by the development of the real estate market, which led to the appearance of a considerable number of applications for mortgage loans. Because of this, real estate prices have risen, borrowed values have risen to a higher value, which in the context of longer maturities and greater sensitivity to changes in interest rates could put pressure on borrowers' ability to meet debts. At the same time, the exposures of credit institutions related to the real estate market remained at a significant level. Therefore, it is very important to maintain the LTV level (loan-to-collateral ratio) at prudent values.

The solution to reduce bank delinquency is the orientation in a higher proportion towards fixed interest loans, as well as the application of measures regarding the degree of indebtedness of the population in order to maintain in the prudential parameters the evolutions at the level of lending to the population. In this regard, the NRB took measures to mitigate this risk, namely implemented a capital buffer for systemic risk and strengthened the regulatory and supervisory framework of NFIs by introducing new entry criteria under the prudential supervision of the central bank. Thus, the aim is to prevent the excessive indebtedness of the population, to support a sustainable lending in lei for a longer period and to orient the business model of the banks towards financing the companies sector.

We can say that there would be many things to improve on the part of corporate governance at the level of banks, so that the degree of professional training of banking staff to increase. In this regard, employees should be recruited on the basis of clear professional criteria and subsequently trained by participating in specialized courses that take into account not only the sales process, but also the understanding of the procedure behind the sale. Unfortunately, banks place great emphasis only on quantitative sales, the targets imposed on employees being large enough 
so that they no longer analyse the ability to repay customers, their profile, their desire to borrow in conjunction with the subsequent level of repayment. Unfortunately, the system in which a customer's data is entered can be easily fooled, in the sense of intentionally ticking some data that do not correspond to reality, thus facilitating lending, but increasing the risk of non-repayment of credit. For this reason, the NRB has issued much more severe sanctions for non-compliance with data processing or protection of personal data[10].

The year 2019 marked the imposition of both quantitative and qualitative cards, so employees are determined to strictly comply with data protection rules and, at the same time, meet the required indicators. Thus, some banks have managed to clean the portfolio of unwanted, nonperforming customers, which increase the degree of delinquency of the bank. The receivables were sold to enforcement offices, increasing the number of cases on this side.

The assignment to the executor is made by declaring the credit as non-performing, the bank constitutes a risk provision, in some cases it does not proceed to forced execution or insolvency, the claim is sold to a subsidiary owned by the bank. Thus, the debt passes "from one pocket to another". Assignment of receivables is the operation by which the creditor voluntarily transmits, for a fee or free of charge, the right of claim to another person named assignee, thus becoming a creditor in his place, being able to collect from the debtor the assigned claim[11].

Regarding legal entities, we can say that a level of vulnerability exists at the structural level. Large companies have a high enough concentration in the market so as to negatively influence it if they enter a difficult situation. These elements represent another moderate systemic risk[12].

The pandemic with COVID19 has brought with it a series of drastic measures imposed by the government to limit its spread. As a result, many people have lost their jobs or become technically unemployed. This crisis has led to the inability to pay the instalments. In this regard, the government has adopted a series of measures that sought to help the population in a critical situation. Banks have agreed to the law of postponing rates by up to 9 months, no later than the end of this year[13]. However, the banks have a series of costs in this respect, materialized in the payment of interest during the deferral period during the remaining credit years, for the unsecured ones or for the next 5 years for the mortgage ones. Of course, the contractual period is extended by the number of months postponed for payment.

The companies suffered a lot during this period, especially those with a field of activity that involved the participation of customers. For each 
of them, a personalized plan has been established for the payment of installments due after the pandemic.

Many of the banks on the market have tightened their lending conditions, both for individuals and for legal entities. While some banks have stopped lending to new customers, focusing on those in their portfolio, others are no longer lending at all. At the same time, the credit platforms have dropped considerably, those who have postponed their rates will be restricted for a period of time from taking out more loans. The level of LTV has reached $65 \%$, the levels of advances for mortgage loans being increased, so that banks can take the necessary precautions[14]. We emphasize that every decision to prevent the growth of banking delinquency belonged to each bank.

For SMEs, a financing program with state guarantees has been implemented, at advantageous interest rates to help them overcome these months of restrictions [15].

\section{Conclusions}

The tightening of macroeconomic balances, coupled with a potential deterioration in investor sentiment towards emerging markets, rising indebtedness and vulnerabilities in corporate balance sheets, remains worrying, as it can put pressure on financial stability by amplifying the effects on borrowers' ability to pay either through the channel of interest rates, or through the channel of exchange rate.

The banking sector was characterized by levels of capitalization and robust liquidity, by an increasing profitability, but also by declining values of the non-performing loans rate. Therefore, new potential risks to financial stability could be generated by the high level of sovereign exposures, especially those related to the real estate market, in the banks' portfolios, but also by foreign currency financing or the rapid growth of NFI lending. Therefore, a number of measures have been taken to introduce new regulations on real estate exposures, more pro-liquidity management and further support of the development of the crisis surveillance and management framework.

The pandemic has rearranged the banks' priorities, creating a state of panic among the population due to the possibility of non-payment of instalments. The government came up with a series of regulations, the banks tightened lending conditions, focusing on their own portfolio.

\section{Acknowledgement}

This work is supported by project POCU 125040, entitled "Development of the tertiary university education to support the economic growth - 
PROGRESSIO", co-financed by the European Social Fund under the Human Capital Operational Program 2014-2020

\section{References}

[1] „Uniunea bancară”. Available from: http://www.consilium.europa.eu/ro/policies/banking-union/

[2] Treapăt L-M. Managementul si asigurarea riscurilor bancare in Romania. Bucureşti: Economică; 2011.

[3] King M. Sfârşitul alchimiei- Banii, băncile și viitorul economiei mondiale. București: Comunicare.RO; 2016.

[4] Danescu AC. Controlul intern al raportarii financiare- Practici de transparenta si credibilitate bancara. Economică; 2014.

[5] Peicuți C. Lumea in criză-Erorile sistemului. Bucureşti: Polirom; 2011.

[6] Dedu V. Gestiune şi audit bancar, Ed. a 2-a. Bucureşti: Economică; 2008.

[7] Badea L, Socol A, Dragoi V, Driga I. Managementul riscului bancar. București: Economică; 2010.

[8] „Banca Națională a României - Publicaţii periodice”. Available from: https://www.bnr.ro/Publicatii-periodice204.aspx\#ct100_ctl00_CPH1_CPH1_19966_lnkTitle

[9] Comisia Naţională de strategie şi prognoză. Reguli privind calcularea şi publicarea indicelui zilnic şi a indicelui de referinţă trimestrial, reglementaţi de OUG nr. 19/2019 pentru modificarea şi completarea unor acte normative. Available from: http://www.cnp.ro/user/repository/OUG_114_2018/ Reguli_indici.pdf.

[10] Autoritatea Națională de Supraveghere a Prelucrării Datelor cu Caracter Personal. Pagina principală. Available from: https://www.dataprotection.ro

[11] Coltuc M. Buna ziua Brasov. „Ce poti face daca banca vinde creanta unei societati de recuperari creante; 2912. Available from: https://www.bzb.ro/stire/ce-poti-face-daca-banca-vinde-creanta-uneisocietati-de-recuperari-creante-a9852

[12] F. Intelligence, „BNR: Probabilitatea de nerambursare a creditelor acordate populației s-a reînscris pe un trend ascendent", Financial Intelligence, iul. 13; 2018. Available from: https://financialintelligence.ro/bnr-probabilitatea-denerambursare-a-creditelor-acordate-populatiei-s-a-reinscris-pe-un-trendascendent/

[13] Guvernul României. „SStiri”. Available from: https://gov.ro/ro/stiri

[14] „ING Romania. Stam Acasa. Available from: https://ing.ro/lp/informatiiutile-coronavirus

[15] „IMM INVEST România. Acasă. Available from: https://www.imminvest.ro/ 